\title{
Dynamics of Physical Properties of Ultisol under Corn Cultivation in Wet Tropical Area
}

\author{
Yulnafatmawita $^{\# 1}$, Dendy Detafiano ${ }^{\#}$, Prakarsa Afner ${ }^{\#}$, Adrinal ${ }^{\# 2}$ \\ \# Soil Science Department, Andalas University, Kampus Limau Manis Padang, 25163 Indonesia \\ E-mail: 'yulna_fatmawita@yahoo.com, ${ }^{2}$ adrinal81@yahoo.com
}

\begin{abstract}
Cultivation will change some of soil physical properties which determine the susceptibility to erosion. Therefore, the properties must be paid much attention in cultivating soil for annual crop farming, such as for corn. A research about dynamics of physical properties of Ultisol was conducted during corn cultivation in Ultisol Limau Manis, a wet tropical area. The objective of the research was to determine the changing of the soil physical properties during corn cultivation. The soil was sampled before cultivation, 1, 2, and 3 months of corn age, and 3 weeks after harvesting. Parameters analyzed were soil texture, bulk density, total pore, aggregate stability, soil moisture, organic $\mathrm{C}$, permeability. The result showed that there was a short term effect of corn growth on some physical properties such as bulk density, total pore, aggregate stability, permeability, and organic matter content of the Ultisol. The properties tended to improve during corn age 2 and 3 months, and then get down again after harvesting.
\end{abstract}

Keywords - corn cultivation; soil physical properties; Ultisol; wet tropical area

\section{INTRODUCTION}

Ultisol is considered as a marginal soil, an unfertile soil which is not considered for crop production in agriculture since fertile soils are still available. This is due to the fact that the soil has poor physico-chemical properties. Besides having bad soil chemical properties [3] causing low plant growth performance, Ultisol has also poor soil physical properties, while they play an important role in affecting soil productivity. Yulnafatmawita [10],[7],[9] reported that this Ultisol had very high clay content $(>70 \%)$ but low SOM. This condition brings the soil into low aggregate stability and slow infitration and permeability rate. Therefore, this soil is susceptible to erosion if it is cultivated, especially under high rainfall and sloping area such as in West Sumatra.

However, intensive land use change lately has caused the Ultisol to be open and cultivated for annual crop farming. This is caused by the fact that fertile soil has been changed into non-agricultural use. Moreover, natural disasters have also increased the amount of marginal land. Therefore, Ultisol as a marginal land was started cultivating. Area of the Ultisol reached 45.8 million ha in Indonesia [6], in which most of the Ultisols was uncultivated. Cultivation of the soil especially for seasonal crops leads to alter the physical properties. Yulnafatmawita [10] reported that amount of soil loss at Ultisol Limau Manis could higher than the tolerated erosion.
Soil physical properties not only determine susceptibility of the soil to erosion, but also affect soil chemical properties. High nutrient content in a soil will mean nothing if there is not enough water available for plant growth. Furthermore, good balance between water and air in a soil will also facilitate plant root development, therefore, nutrients contained in the soil can be uptake by plants.

Tillage practices and plant growth are among factors affecting soil physical properties. Tillage will cause soils to be looser, and exposed to raindrops. Plant canopy and root development, on the other hand, can protect soils from being degraded by external factors and eroded. Ghestem et al [2] stated that root architecture and diverse consequently affect preferential flow. Yulnafatmawita et al reported that amount runoff and soil eroded decreased as corn grew [10]. Dynamics of soil physical properties can be determined in a short time from cultivation of annual crops, such as corn.

\section{MAterial AND MethodS}

This research was conducted at Ultisol in Limau Manis, a wet tropical area in West Sumatra Indonesia. A piece of land having $25 \%$ slope was planted with corn (Zea mays). Soil samples were taken at 5 different times (before tillage, 2 weeks after tillage or at planting time, 6 weeks after planting, 10 weeks after planting, and 2 weeks after harvesting. Disturbed and undisturbed soil samples were taken on 0-20 $\mathrm{cm}$ depth for analyses for the physical properties. Parameters analyzed were soil texture (sieve and pipette 
method), hydraulic conductivity (constant head method), organic matter content (wet oxidation method), bulk density, total pore, and moisture content (gravimetric method). The data resulted were compared to soil criteria.

\section{RESULT AND DISCUSSION}

\section{A. Initial Soil Properties}

In general, Ultisol used in this research, under wet tropical climate, had bad soil characteristics. Physically, the soil was dominated by smallest particle or clay $(83.20 \%)$ and very low SOM content $(1.16 \%)$ (Table 1). It means that the soil had low soil aggregate stability, unbalance between macroand micro-aggregate percentages, even though it had medium percentage of total pore space $(57 \%)$. The soil was high micro-pores but low in macro-pores. Therefore, the aeration and drainage of the soil was rather limited.

High clay content combined with low SOM and high soil $\mathrm{BD}$ described that the soil had low infiltration rate. This will initiate run-off, especially the soil had relatively high soil moisture content $(56 \%)$, which is more than half of the volume. Since the research area was located under super wet tropical region, the probability of erosion occurs was high enough.

Low aggregate stability of this soil caused the soil very susceptible to erosion, especially water erosion, since the annual rainfall in the area approximately $5000 \mathrm{~mm}$ or more /year) in this area. Water erosion becomes worse as the soil open such as for corn cultivation.

TABEL I.

INITIAL SOIL PROPERTIES OF ULTISOL LIMAU MANIS

\begin{tabular}{|l|l|}
\hline Parameter & Value \\
\hline $\mathrm{pH} \mathrm{H}_{2} \mathrm{O}$ & 4.9 \\
\hline Exch.-Al (me/100 g) & 1.9 \\
\hline Soil moisture $(\mathrm{g} / \mathrm{g})$ & 0.42 \\
\hline Soil moisture (v/v) & 0.48 \\
\hline Void ratio (e) & 1.33 \\
\hline Degree of saturation (s) & 0.85 \\
\hline Particle size distribution & \\
\hline$\%$ sand & 15.10 \\
\hline$\%$ silt & 1.74 \\
\hline$\%$ clay & 83.16 \\
\hline Soil organic matter $(\%)$ & 1.16 \\
\hline BD (g/cm $\left.{ }^{3}\right)$ & 1.15 \\
\hline Total pore (v/v) & 0.57 \\
\hline Hydraulic conductivity $(\mathrm{cm} / \mathrm{h})$ & 0.26 \\
\hline Soil Dispersion Index & \\
$-\quad$ DR 20 & 0.22 \\
- DR 2 & 0.05 \\
\hline
\end{tabular}

Besides bad soil physical properties, the Ultisol also had low level of soil chemical properties. It had acid reaction $(\mathrm{pH}<5.0)$ and high exchangeable Al. Acid will cause limited nutrients available in soil, while $\mathrm{Al}$ is toxic for plant growth. Therefore, this soil is known as marginal soil that must be conserved for the use, especially for annual crop farming, such as corn.

\section{B. Soil Moisture Content}

Field soil moisture content changed throughout of corn cultivation. Soil moisture content was high enough during the first 2 stages of corn growth, and then decreased at the last three stages. Higher soil moisture content at the first two stages was probably due to low water absorbed by crops, since they were still young. While at the last three stages, lower soil moisture content could be caused by higher water absorbed during maximum vegetative growth and as well as during kernel filling. Furthermore, the soil moisture content of Ultisol was much depent on the amount of rainfall received in the research area (Figure 1).

\section{Soil Bulk Density}

As soil moisture content, soil bulk density value also varied during corn cultivation. It tended to decrease as the second and the third stages of corn growth compared to the first stage. This was due to the fact that tillage causes soil become porous. Then, it continued decreasing as crop growth until the fourth stage due to maximum root development and wider soil coverage by plant canopy. As the corn comes into maturity (stage 4 ) the soil bulk density tended to be level off, and then increased after harvest time back.

Unlike the fact as reported by Yulnafatmawita et al that SOC content was inversely related to soil bulk density[7],[9]. This unusual result seems to be due to low canopy of crops and decaying of some roots. Plant canopy protects soil surface from kinetic energy of rain drops to degrade the aggregate causing soil compaction. The more rainfall drops, the more compacted soil leading in higher soil bulk density under less plant canopy. As reported by Cavalieri et al, that deterioration of soil structural quality led an increase in bulk density [1].

Like soil moisture content, soil bulk density seems to be linearly related to the amount of rainfall received in the research area (Figure 2). As reported by Kumar et al, that the dynamic soil properties were influenced by many factors such as confining pressure, methods of loading, over consolidation ratio, loading frequency, soil plasticity, percentage of fines and soil type [4].

Furthermore, soil bulk density tended to inversely related to soil organic carbon (Figure 3). Soil organic carbon having high soil moisture causes soil bulk density or dry weight of soil in each certain soil volume decreases. Likewise, soil bulk density was also negatively correlated with soil hydraulic conductivity (Figure 4). 

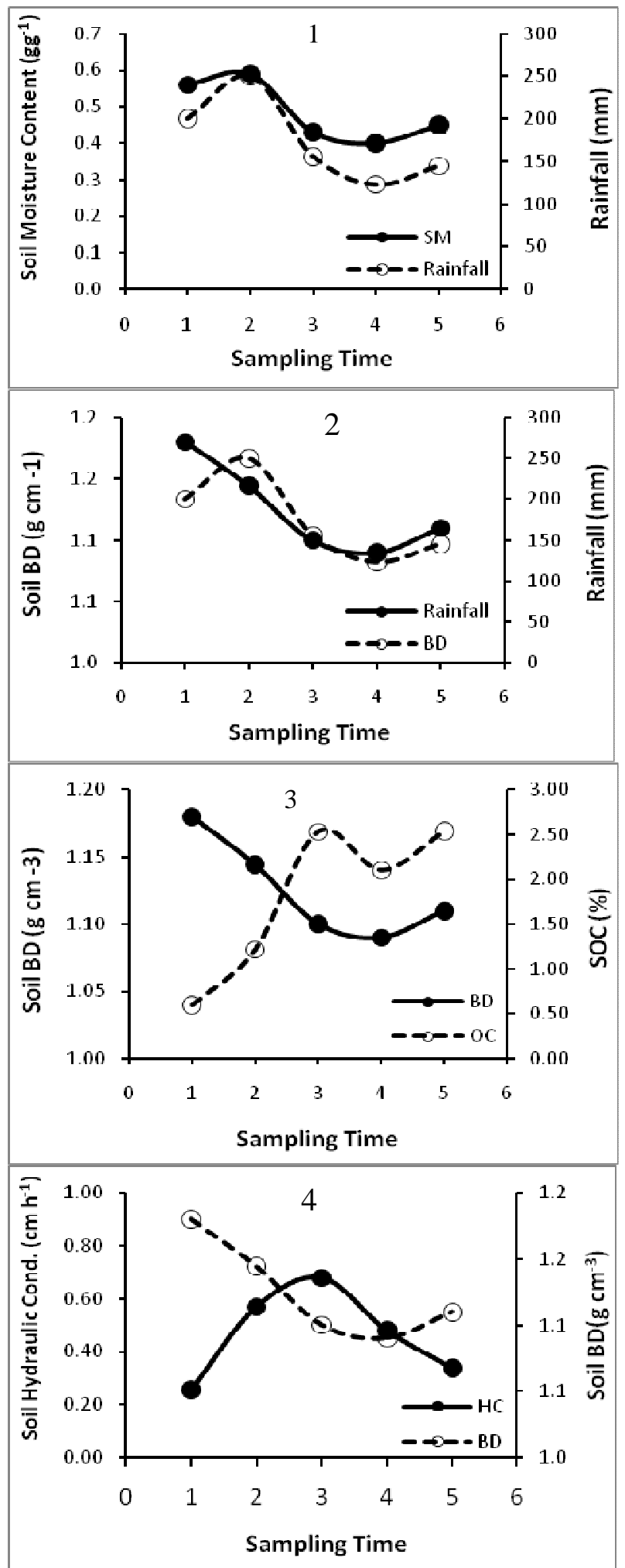

Fig. 1-4: Dynamics of soil physical properties (1) soil moisture, (2) soil OC vs soil bulk density (3), and soil hydraulic conductivity (4)

\section{Soil Organic Carbon}

Soil organic carbon content of Ultisol increased during corn cultivation (Figure 5). The sharpest increase was found during the third stage. This was due to intensive activity of crop growth either above or below ground. Therefore, it contribute more organic $\mathrm{C}$ especially from root activity. Plant roots during the growth will release organic acids to the medium, in this case into soil. As reported by that almost $5 \%$ to $21 \%$ of all photosynthetically fixed carbon was transferred to the rhizosphere through root exudates [5]. The exudates released by the roots correlates to the plant growth activity.

As plants grow intensively, the roots also release more OC. At the fourth or maturity stage, the SOC content slightly decreased and then increased two weeks after harvesting. Higher SOC at last stage of corn cultivation was probably due to contribution of root decay after harvesting. Besides root contribution, increasing SOC content could also due to decomposition of weeds found on the plot before tilling the soil.

Soil organic carbon content of the soil was not affected by rainfall, but it affected percentage of total soil pore (Figure 6). Figure 9 showed that there was a positive-linear correlation between SOC content and total soil pore. Sixty nine percent $(69 \%)$ of increasing total soil pore was due to SOC content. This was due to the role of SOM in creating and stabilizing soil aggregates. Aggregation process created larger soil pores causing more space between aggregates, and therefore, increasing SOM content decreased dry weight per unit volume of the soil or the value of the bulk density. As showed in Figure 10, 85\% of soil bulk density was due to SOM content.

Soil organic carbon also affected soil hydraulic conductivity (Figure 7). Soil hydraulic conductivity followed the SOC content from the beginning until the fourth stage. However, at the last stage as corn had been harvested and the soil became bare as well as the plant roots decayed, the soil hydraulic conductivity decreased back.

\section{E. Total Soil Pore}

In general, total soil pore increased by the time of corn growth, but it went down again as corn was harvested. Increasing soil total pore at the second stage was due to soil tillage before corn planted. Tillage causes the soil becomes looser, or the soil volume becomes higher. Furthermore, continous increase in total pore of the Ultisol at the thid and the fourth stages was probably due to root mass and activity. Higher root mass in the soil as it is profilition decreases soil bulk density, in turn causing higher total soil pore. Furthermore, the activity of the roots in their developments such as breakthrough soil mass has caused the soil to be looser. On the other hand, as root activity stoped and the soil surface exposed to rain drops, the soil became more compact, therefore, the total soil pore decreased.

Total pore of a soil was inversely related to the bulk density of the soil (Figure 8). Since the soil OC content was not so high, the value of the total soil pore was $96 \%$ determined by the soil BD (Figure 11). 

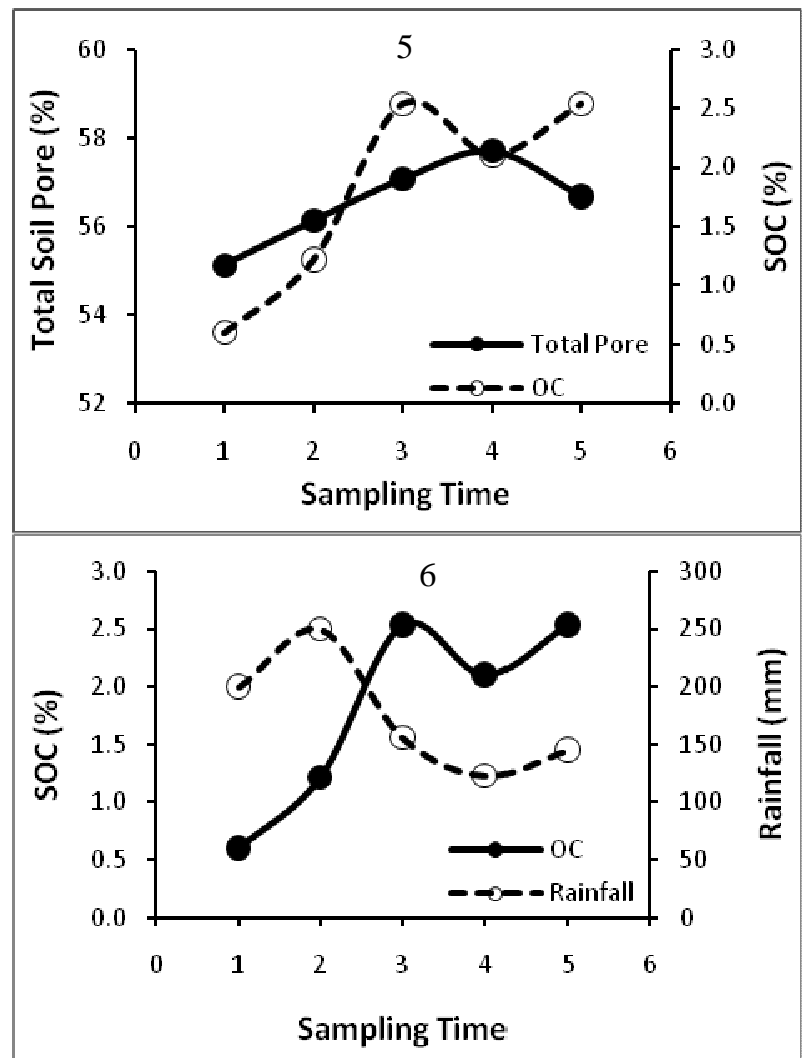

Fig. 5-6: Dynamics of soil physical properties (5) total soil pore vs SOC and (6) SOC vs rainfall

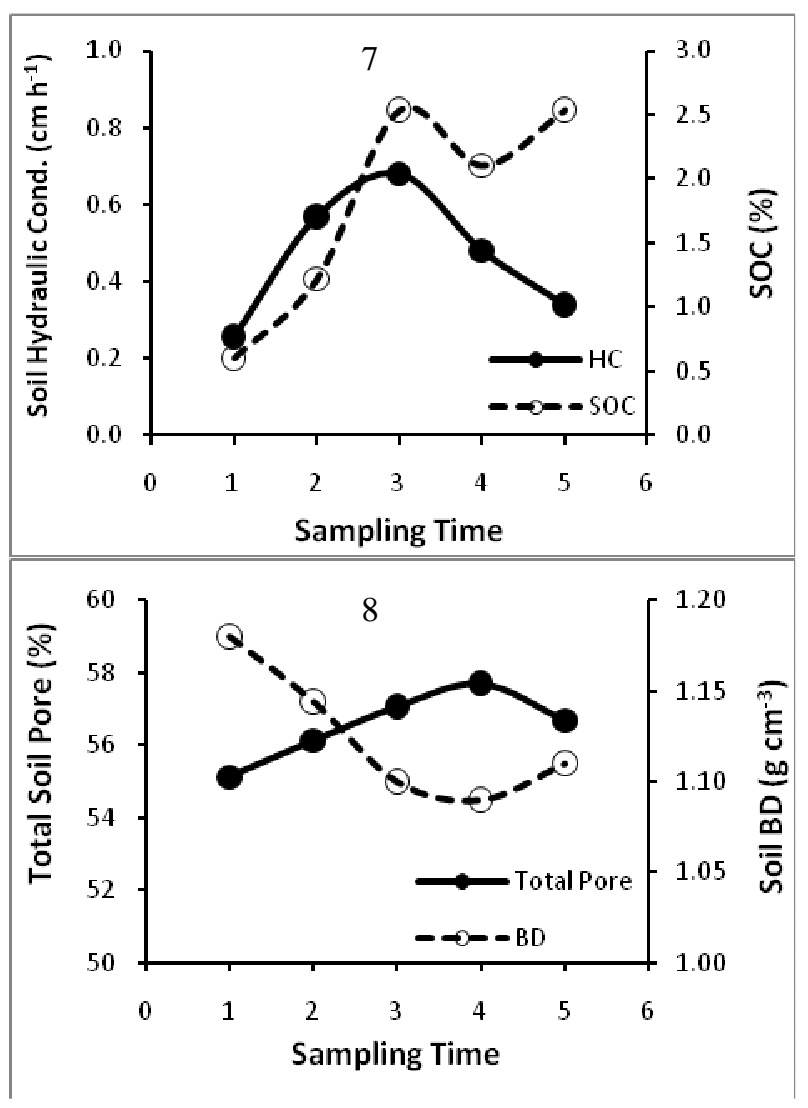

Fig. 7-8: Dynamics of soil physical properties (7) soil hydraulic conductivity vs SOC, (8) total pore vs soil BD

\section{F. Soil Hydraulic Conductivity}

The ability of soil to transmit water through its pores or hydrailc conductivity values of Ultisol during corn cultivation varied by time. The value increased from the first to the second and the third stages sharply, and then decreased back at the fourth stage, and continued decreasing until the fifth stage. This increase was probably due to soil cultivation.

Cultivating soil increased soil macro-pore percentage, therefore, the water became easy to be transmitted through the pore. However, since the soil had low SOC and high clay content, the hydraulic conductivity of the Ultisol was classified as low.

High clay with low soil OC content caused the Ultisol easy to degrade, especially after being open and tilled for annual crop farming. The condition was very susceptible to raindrop impact on the soil surface. As reported by Yulnafatmawita et al that amount of runoff and soil eroded were the highest during the last month of corn growth compared to the first and the second months [10].

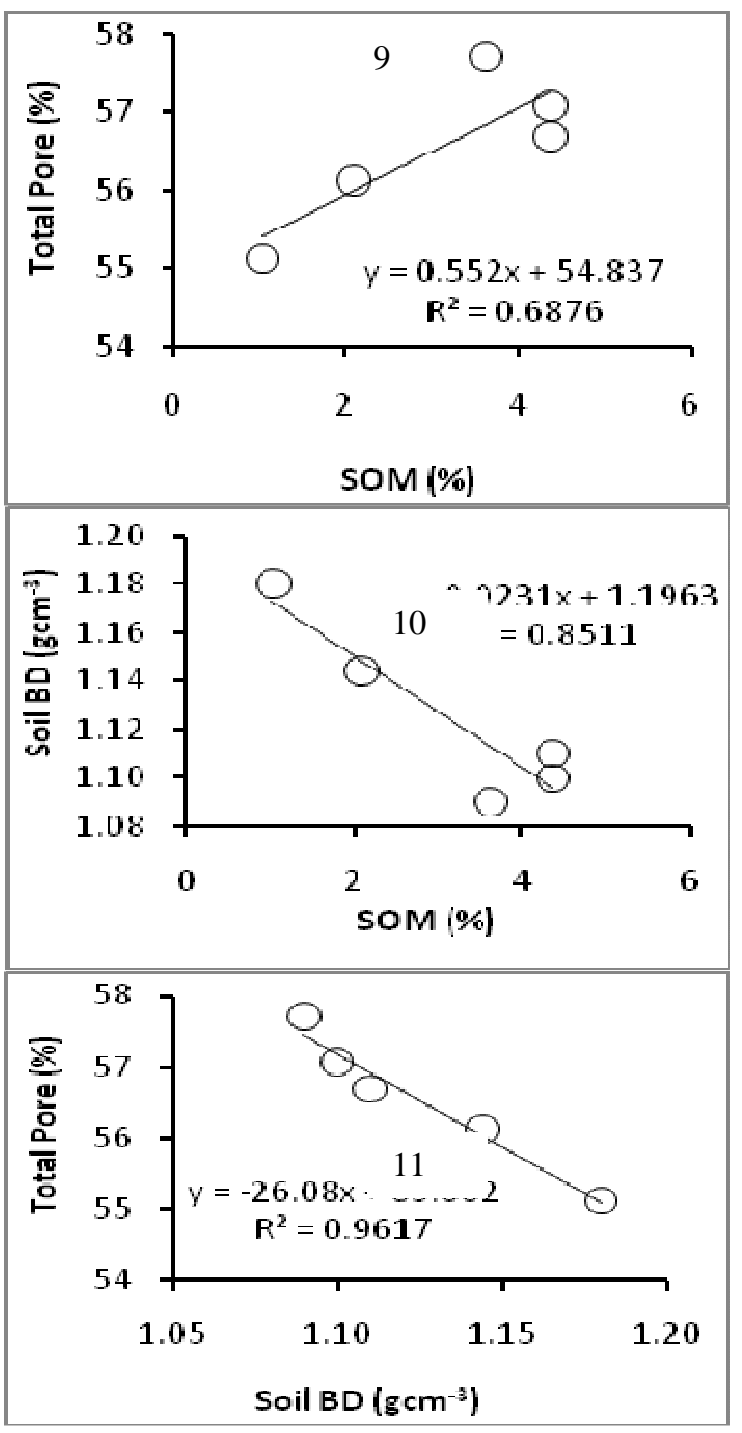

Fig. 9-11: Relationship between (9) total pore and SOM, (10) soil BD and SOM, and (11) total pore and soil BD 
Except soil texture, soil physical properties fluctuated during corn growth in Ultisol under tropical area. This was not only due to the cultivation process, tillage and root and canopy development, but it was also affected by the rainfall received in the area. As reported by Yulnafatmawita and Adrinal that there were fluctuations in physical properties of Ultisol during the cultivation causing changes in the amount of runoff and soil loss in wet tropical area [7].

\section{CONCLUSIONS}

Based on the results above it could be concluded that there was fluctuation in soil physical properties under corn cultivation in wet tropical area for one planting season. Soil moisture content was strongly correlated to rainfall amount. Soil organic carbon content as well as total soil pore generally increased by time. On the other hand, soil bulk density decreased by time except at last stage. Soil hydraulic conductivity increased from the beginning until the third stage and then decreased back from the third to the fifth stages of corn growth.

\section{REFERENCES}

[1] Cavalieri, K.M.V., da Silva, A.P., Tormena, C.A., Leão, T.P., exter, A.R., Håkansson, I. 2009. Long-term effects of no-tillage on dynamic soil physical properties in a Rhodic Ferrasol in Paraná, Brazil. Soil and Tillage Res. Vol. 103 1) : 158-164

[2] Ghestem,M., Sidle, R.C., and Stokes, A. 2011. The influence of plant root systems on subsurface flow: Implications for slope stability. Bioscience 61: 869-879
[3] Hakim, N., Agustian, and Hermansah. 2008. Pemanfaatan agen hayati dalambudidaya dan pemanfaatan titonia sebagai pupuk alternatif dan pengendali erosi pada Ultisol. Laporan Penelitian Hibah Program Pascasarjana Tahun II. DP2M Ditjen Dikti dan Program Pascasarjanan. Unand Padang

[4] Kumar, S.S., Krishna, A.M., and Dey, A. 2013. Parameters Influencing Dynamic Soil Properties: A Review Treatise. National Conference on Recent Advances in Civil Engineering; November 1516 th,

[5] Marschner, H. 199. Mineral Nutrition of Higher Plants. Academic Press, London, Ed 2.

[6] Subagyo, H., Suharta, N., and Siswanto, A.B. 2004. Agricultural soils in Indonesia. In: A.Adimihardja, L.I. Amien, F. Agus, and D. Djaenuddin (eds). Land Resources and Its Management in Indonesia. P3T and Agroklimat. Deptan. pp 21-65 (in Indonesian)

[7] Yulnafatmawita and Adrinal. 2014. Physical characteristics of Ultisols and the impact on soil loss during soybean (Glycine max merr) cultivation in a wet tropical area. Agrivita J.A.S., vol. 36(1): 57-64. ISSN : 0126-0537

[8] Yulnafatmawita, Gusnidar, and A. Saidi. 2010. Role of organic matter in situ for aggregate stability improvement of Ultisol in West Sumatra and chili (Capsicum annum) production. Proceeding ISFAS (Int'l Seminar on Food and Agric. Sci.) 17-18 Feb. 2010, Bukit Tinggi, Indonesia.

[9] Yulnafatmawita, Adrinal, and Febrian Anggriani. 2013a. Fresh organic matter application to improve aggregate stability of Ultisols under wet tropical region. J Trop Soils, Vol. 18 (1): 33-44. ISSN 0852-257X

[10] Yulnafatmawita, S. F. Nasution, and Adrinal. 2013b. Short term dynamics of soil erosion and nutrient loss during corn growth in Ultisols Limau Manis Padang. Proceeding ESAFS, 18-21 October in Bogor, Indonesia. 